Vol. 8, Issue 8, August 2021

DOI: $10.17148 /$ IARJSET.2021.8871

\title{
Tendencies and treatment of themes in Mizo Fiction
}

\author{
Dr. Zoramdinthara ${ }^{1}$, Enid H Lalrammuani ${ }^{2}$. \\ ${ }^{1}$ Associate Professor, Department of Mizo, Mizoram University. \\ ${ }^{2}$ Asst. Professor, Department of Mizo, Pachhunga University College.
}

\begin{abstract}
Mizo fiction written in Mizo tawng (Mizo language) of the Mizo peoples is an important branch of Mizo literature. Mizo literature underwent significant changes in 1920s when large number of poetry and drama appeared in the hands of literary men. This is mainly due to the arrival of Christian missionaries and it was an age of peace and social contentment. Christianity soon spread to the whole of Mizoram and in no time, many people were converted into Christian. "Christianity began to stop their primitive pre-notion that huai (demons) lived in caves, trees, a small mound in a jhum and to give up such superstitions, the Lushai Superintendent had taken strong initiative and made an order that those who were involved in such superstitions will be accused...that is why the period may be regarded as Golden Period". As such there is no major obstacle that can hamper the growth of Mizo fiction and this peaceful atmosphere in the land became manure for further development of Mizo fiction. Therefore, this paper will be an attempt to reflect or highlight kinds of tendencies and theme of Mizo fiction.
\end{abstract}

\section{INTRODUCTION}

Mizo fiction written in Mizo tawng (Mizo language) of the Mizo peoples is an important branch of Mizo literature. Mizo literature underwent significant changes in 1920s when large number of poetry and drama appeared in the hands of literary men. This is mainly due to the arrival of Christian missionaries and it was an age of peace and social contentment. B. Lalthangliana has rightly said, "There was no more fighting between one village to another village, materialism had no place in their minds, no hatred among them and everyone enjoyed a peaceful atmosphere," (Lalthangliana, Mizo 169). Christianity soon spread to the whole of Mizoram and in no time, many people were converted into Christian. "Christianity began to stop their primitive pre-notion that huai (demons) lived in caves, trees, a small mound in a jhum and to give up such superstitions, the Lushai Superintendent had taken strong initiative and made an order that those who were involved in such superstitions will be accused...that is why the period may be regarded as Golden Period" (ibid 169). Through the teaching of Christianity, education became more popular and lower and upper Primary School was established in many villages of the district As such there is no major obstacle that can hamper the growth of Mizo fiction and this peaceful atmosphere in the land became manure for further development of Mizo fiction. From the literary point of view, traditional Mizo poetry, secular poetry and Christian poetry flourished during 1920 - 1930. Patea (1894-1950) was the one who introduced Christian poetry. "By his first song, $K a$ ropuina tur leh ka himna hmun, Patea opened a new chapter in the history of Mizo Christian poetry in 1920" (Thanmawia 79). In no time, they were supported by other poets. Similarly, Mizo drama also began to sprout with the celebration of Christmas in Mizoram. In this connection Lianhmingthanga said, "In 1912, Christmas day was celebrated in most of the villages with a grand feast. The Christmas Day 25 December 1912 will always be remembered in the history of Mizo drama, because in the evening of this every day, the first ever dramatic performance was held in a small thatched roofed theater of Thakthing veng, Aizawl. With the initiative of the missionaries, the most successful function of variety entertainment was shown to the people for the first time" (Khiangte, Mizo Drama 33).

In short, a cursory survey of the beginning of written Mizo literature shows that before the birth of Mizo fiction, poetry and drama have already flourished and was well acquainted in Mizoram. Before the arrival of Christianity in Mizoram, the Mizo did not know drama, secular and Christian poetry. But, when they reached the land, the Welsh missionaries used poetry and drama as one of the important tools for the spread of Christianity in Mizoram. In this way, the missionaries prepared grounds for the growth of poetry and drama.

The year 1936 may be one of the most significant periods in the literary history of Mizo literature and it marked the beginning of Mizo fiction. The first period of Mizo fiction may be called Pre-Independence period (1936 - 1946) and during these period three fiction writers emerged, namely - L. Biakliana, Kaphleia and Lalzuithanga. B. Lalthangliana called these three pioneer writers "three wheels of Mizo Novel" (Lalthangliana, Ka 207). As such, the literary horizon of Pre Independence Mizo fiction was dominated by only three writers namely, L. Biakliana, Kaphleia, and Lalzuithanga who lived in the same period. It is indeed that these three men brought this new genre in Mizo literature. During this period, fiction was not as developed as poetry was. But it was remarkable for the first time in the history of 


\title{
International Advanced Research Journal in Science, Engineering and Technology
}

\author{
Vol. 8, Issue 8, August 2021
}

\section{DOI: $10.17148 /$ IARJSET.2021.8871}

Mizo fiction that ten fictions emerged in the Pre Independence era. After these writers, there came an emergence of various literary tendencies, which came through various writers. As life underwent many changes after India's Independence, Mizo fiction writers became more aware of these changes and their writings as a result of such changes came out in a multitude of tendencies. In Post-Independence up to 1986, there increased number of fiction writer and there emerged twenty four fiction writers. Out of these, eighty three fictions appeared in the post-independence era. Even in the Modern Mizo fiction, the figure is tremendously increased that hundred thirty seven fictions have emerged in the hands of various writers. During this period, we can note with interest the following major fiction writers like Laizawna, Lalruali, H. Lallungmuana, Lalhmingliana, Lalngurliani, C. Lalnunchanga, Lalhriata, Rozamliani, Lalrammawia Ngente, Chhantluanga, Lalpekkima and Samson Thanruma.

\section{METHODOLOGY}

Though Mizo fiction is the youngest among the branches of Mizo literature; it played a significant role in Mizo literature. This is due to the fact that it rejected all the cramping limitations of traditions and rules. In fiction traditions and rules can sometimes be ignored. At the same time, Mizo fiction offered a fresh field and wider scope in which writers are able to work independently. It deals with ordinary events, ordinary people and life and all sorts of matters. It is positive that the future of Mizo fiction is secure and it has assumed the role of a legend in Mizo literature. This has indicated by the record of Mizo Academy of Letters who started awarding its Book of the Year in 1989 and during the last ten years, seven Mizo fictions has won Mizo Academy award. The primary source of this paper covers select Mizo fiction since 1936-2000.

\section{RESULT AND DISCUSSION}

Though Mizo fiction is the youngest among the branches of Mizo literature; it played a significant role in Mizo literature. This is due to the fact that it rejected all the cramping limitations of traditions and rules. In fiction traditions and rules can sometimes be ignored. At the same time, Mizo fiction offered a fresh field and wider scope in which writers are able to work independently. It deals with ordinary events, ordinary people and life and all sorts of matters. It is positive that the future of Mizo fiction is secure and it has assumed the role of a legend in Mizo literature

Trend of Mizo fiction reveals that Mizo fiction writers approached morality from their own perspective. As a religious preacher intends to transport about reforms through his teachings and as a judge wants to change the decaying of society through his verdicts, Mizo fiction writers also utilised their fiction as a platform to bring about changes social evil in the society. However, they too believed that only through ethical attitude social changes are possible. For major fiction writers like Biakliana, Kaphleia, Lalzuithanga, C Thuamluaia, Zikpuii pa, Khawlkungi, Lalengmawia, Laizawna, etc fiction writing was for social changes in the society. They believed in the purity of action, sincerity of heart and ethical approaches and they saw society extremely hankering for changes. For example, in Lali by Biakliana, the heroine Lali though physically depraved had a sincere heart and a pure emotion. In short all the heroes and heroines of Mizo fiction tried to help others though they themselves felt a victim of many mental and physical agonies, yet they are pure at heart and always sincere in their intentions.

Poetic justice is sometime appeared in Mizo fiction. It is an idea that the good are rewarded and the evil punished. But literary history of Mizo fiction makes quite clear that there is partly a poetic justice in Mizo fiction. This is because all the Mizo fiction writers are Christian and their philosophy is intensely connected with the belief and faith of Christianity. As such, the theme of punishment or revenge never happened in their fictions. In most Mizo fictions, the heroes and heroines suffer not by their own faults. Sometime the good and even the virtuous are often crushed and they do not get prosperity which they fully deserved. Generally the heroines and heroes suffer terribly out of all proportion to their faults. But, at last religious people are glorified and are successful in different ways. At the same time, evil doers are also blessed, but their end becomes full of sufferings, downfalls, and death. It is thus clear that poetic justice is not a fact of life and so they partly introduce it in their works.

Before contact with the west, Mizo society was conservative and sex was considered a taboo. People never talk about it freely and openly anywhere. If people happen to talk about it in the open, they had a belief that misfortune will fall upon such people. Even after Christianity entered in Mizoram, this taboo on sex still remains and Christian in fact considered sex talks as blasphemy against God. The Mizo fiction writers never depict sex as something disrespectful or humorous. In fact, to them, sex is holy and sexual abuse is considered as turning against God and deprivation of his blessings. For instance, if we look at Zikpuii pa's Nunna Kawngthuampuiah, Chhuanvawra forcefully attempted to have sex with the heroine Ngurthansangi. But, what Ngurthansangi said to Chhuanvawra is that sex must be enjoyed after wedding. Similarly, for H. Lallungmuana, sex before marriage is a sin. This is clearly highlighted in his Ram leh $i$ tan Chauh. Here the hero Chhuana and the heroine Jennie had ample time to have pre-marital sex. The novelist Muana did not allow his characters to have sex before marriage. The same philosophy is advocated by other Mizo fiction writers. If 


\section{DOI: 10.17148/IARJSET.2021.8871}

the character in the fiction indulges in early sex before marriage, all they get back is remorse and guilt. Thus, a study of Mizo fiction revealed that there is no free and frank treatment of sex. Till date this sex taboo is one of the important trends of Mizo fiction.

Love has always been a dominant factor in Mizo fictions and generally romantic treatment of love. This romantic love finally leads to a marriage. Generally marriage in pre Christian era was a civil contract and as such marriage price played an important role. Sometimes, girls were often forced to marry against their will for the sake of a good bride price. At the sometime, marriage in Mizo society was solemnized as a bond of family tie that every parents are careful in selecting a partner for their children. So far as their character is concern, they look into the past history, the family, and their position. Only when no faults are discovered, then marriage would be performed and this is reflected in some of the Mizo fiction. Normally, the hero and heroine fall in love and ended up in marriage unless death falls in between. But it is always a marriage after fighting against hard times and never an easy marriage. On the other hand they depicted, that those who easily marry without commitment are never fruitful. But what different from pre Christian marriage is celebration. However, Christianity has changed the traditional way of marriage. After Christianity in Mizoram, marriage takes place in the church where the Pastor solemnizes the marriage and reception is also organized. In fact, the marriage has become westernized, but some Mizo fictions dealt with the traditions practiced in the primitive society. At the same time, inter- tribe marriage never happen in Mizo fiction. This is one of the remarkable practices which have not been changed by arrival of Christianity. Of course there are stories of love between a Mizo and nonMizo and readers are led to the assumption that they may finally marry. But Mizo fiction writers are keen that they do not marry and this is one of the unique characters of Mizo fiction.

In Mizo fiction, suffering due to war is common and there are thirty fictions dealing with war. War reflected in Mizo fictions were First and Second World War, MNF insurgency, Karen insurgency, Lushai Expedition, and Chhak leh thlang indo (War between the East and the West). Out of sixteen war novelists, C. Khuma, Zikpuii pa, Dokhuma and C. Laizawna are the major war novelists. These war novelists depicted impact of war and how much people suffer. They depict ruthless physical and mental sufferings inflicted upon the innocent civilians following the outbreak of war. In the third Mizo fiction Chhingpuii, the raiders from neighboring village shot dead innocent Rena, and then Chhingpuii was also killed violently. Zikpuii pa's Nunna Kawngthuampuiah also reflected how the innocent suffers. The district capital Aizawl and few other towns and villages suffered heavy gun fire and bombardment at the hands of the Indian Army causing heavy casualties. To topple the Underground Movement, Indian Army was deployed in battalions whose ruthless acts of atrocities were vividly depicted in the course of his novel. Besides, in the name of combing operation, houses were checked even at midnight, curfew imposed, jhum destroyed, civilians beaten and women raped, any opposition to the military operation measures amounted to physical torture. Laizawna and Dokhuma also showed that war leaves nothing, but loss of their ones and calamities. In the same way, most of the Mizo war novelists vividly reflected the sufferings of innocent peoples and suffering reflected in their works were ruthless, torturing, shooting, looting, kidnapping and death.

Positions of women are one important aspect of Mizo fiction. Especially during the traditional Mizo society, women occupied lower position in every aspect of life. Except on limited account, women have no right to inherit property in her owns right. In spite of their low position, they were fully engaged with the household duties. All the day, they did works at jhum weeding grass and collecting vegetables etc for the family. At night time she has to entertain her suitors or inleng till late night. Apart from these, they looked after all the domesticated animals. In case of divorce, her status was worthless and she enjoyed nothing. However, Mizo women have been liberated by Christianity and this clearly indicated by the three pioneer writers, Biakliana, Kaphleia and Lalzuithanga. In the first Mizo fiction Hawilopari, we see vivid picture of the position of women. The village chief's son Khuala tried to marry Pari. Since Khuala did not succeed in marrying her, he tried to defame Pari by saying "I had slept with this girl" and brought the matter to the chief's court. In the judgment of the court Pari was condemned. Pari and her parents were so angry and agitated against the partial judgment of the village's chief. Later on, due to the injustice done to Pari, the angry family, shifted to another village. The same treatment is also found in his second novel Lali. Kapheia also highlights the pitiable condition of Chhingpuii. During this period, a girl is always punishable if she visits her boyfriend and if they do not welcome all men who courted her. On one particular evening, Kaptluanga and his companions were triumphantly returning from hunting an elephant and they were warmly welcomed by the whole villager including Chhingpuii. Here, Chhingpuii shows her love to Kaptluanga by presenting him a single smoke prepared for him. In no time, the news spread throughout the length and breadth of the village. Then all the bachelors in the village turned to be an enemy of Kaptluanga. They curse him and consequently he became paralyzed and suddenly his might diminish day by day. But, Chhingpuii never deserted Kaptluanga and instead she remains loyal to Kaptluanga and gave him all her might. At times if she has an opportunity she often visits him to help and console him. But, from after independence, Mizo women were liberated from the bondage of inequality. This was due to the initiative taken by the Government and 


\section{International Advanced Research Journal in Science, Engineering and Technology}

Vol. 8, Issue 8, August 2021

\section{DOI: $10.17148 /$ IARJSET.2021.8871}

NGO'S, widespread of education, Christianity, and its teaching in the land. As it was reflected in Mizo fiction, Mizo women were given more freedom regarding the choice of their partner.

The present study also reflects the place of money in Mizo fiction. The longing and love of money is inborn in every human beings and it plays a vital role in every society. But, most of the Mizo fiction writers in general show the evil effect of money that they often depicted money as the root of all evils and those who run towards money ultimately suffer. This love of money brought the change that caused a social distinction among the Mizo. Though there is no class distinction in Mizo society, the gulf between the rich and the poor emerged, due to love of money or money power. Till date, love of money is one of the main themes of Mizo fiction

\section{CONCLUSION}

There is no denying the fact that Mizo in general also admire wealth, high education, earthly position, and reputed persons. But, they also have greater respect for church leaders like, Pastor, church elders and religious preachers and they are always headed by their believed in the Bible and its teachings. Therefore, it may be saving to conclude that Mizo society and Mizo fiction are closely intertwined. Mizo society itself is one of the main factors for the rise and progress of Mizo fiction. It is also evident that Mizo fiction writers of these periods were very much interested in writing on social issues. Till date, even ethical, religious issues and impacts of war which affected the life of Mizo also play a vital role.

\section{REFERENCES}

Biakliana. L. "Lali". Aizawl: L.T.L Publications. 3rd ed

Kaphleia. "Chhingpuii”. Aizawl: R.T.M Press. 1990.

Khiangte, Laltluangliana. “Mizo Drama: Origin, Development and Themes”. New Delhi: Cosmo Publications. 1993.

Khiangte, Dr Laltluangliana. "Thuhlaril”. Aizawl: College Text Book Publications. $4^{\text {th }}$ ed. 2006.

Khawlkungi. "Zawlpala Thlantlang”. Aizawl: Khawlkungi. 3rd ed. 2001

Laizawna, C. "Hmangaihzuali”. Aizawl: Runbika. 2nd ed. 1990

Lalthangliana, B. "Mizo Literature”. Aizawl: R.T.M Publication. 1993.

Lallungmuana, Dr. H. "Ram Leh Itan Chauh". Aizawl: G.M Printing Press. 3rd ed. 1998

Lalthangliana, B. "Ka Lungkham - Introduction to Mizo Literature". Aizawl: R.T.M Press.

Lalthangliana, B. "Kaphleia Hnuhma”. Aizawl: R.T.M Press. 1990.

Lalzuithanga. Phira Leh Ngurthanpari. Aizawl: Gilgal Press. 4th ed. 2004

Pa, Zikpuii. "Nunna Kawngthuan Puiah". Aizawl: M.C Lalrinthanga. 2nd ed. 1995.

Sangkima, Dr. Mizos: "Society and Social Change (1890 - 1947)”. Guwahati: Spectrum Publications. 1992.

Thanmawia, R.L. "Mizo Poetry". Aizawl: Din Din Heaven. 198 